\title{
Market Segmentation for Mobile TV Content on Public Transportation by Integrating Innovation Adoption Model and Lifestyle Theory
}

\author{
Chi-Chung Tao
}

Tamkang University, Taipei County, Taiwan, R.O.C.

Email:cctao@mail.tku.edu.tw

Received June 20 ${ }^{\text {th }}, 2008$; revised August 10 $0^{\text {th }}, 2008$; accepted September $16^{\text {th }}, 2008$.

\begin{abstract}
An integrated approach based on innovation adoption model and lifestyle theory for customer segmentation of mobile $T V$ content on public transportation using multivariate statistical analysis is proposed. Due to high daily trips and different train types Taiwan Railway Administration is chosen as the case study. Firstly, the content of mobile TV on the train are identified as the segmentation variable and key factor facets for mobile TV content are renamed by using factor analysis. Then, the cluster analysis is used to classify customer groups which are named by analysis of variance (ANOVA) and market segmentations are described with demographic, lifestyle and train patronage variables by using cross analysis and Chi-squared independence tests. Finally, this paper discusses empirical results to provide valuable implications for better mobile TV content marketing strategies in the future.
\end{abstract}

Keywords: mobile TV, market segmentation, multivariate statistical analysis

\section{Introduction}

Mobile TV has been widely discussed among different players in the telecommunications and media industry. Mobile operators, which face the saturation of voice services and a declining ARPU (Average Revenue Per User), hope that the TV concept in the mobile phone will be the next killer application. According to analysts' predictions, mobile TV will become a service with significant market size. The valuations of the global mobile TV market vary across different analysts, from US\$ 5.5 billion in 2009 to US\$ 28 billion in 2010. A list of different analysts' predictions is shown in Table 1[1,2].

There are many trial projects confirming future success of mobile TV worldwide using different technologies and business models $[3,4,5]$. Currently three standards are competing with each other: Digital Video Broadcasting Transmission System for Handheld Terminals (DVB-H), MediaFLO and Digital Multimedia Broadcasting (DMB)

Table 1. Global mobile TV market values

\begin{tabular}{lll}
\hline \multicolumn{1}{c}{ Analyst firm } & Year & Prediction of market size \\
\hline Datamonitor & 2009 & US\$ 5.5 billion \\
Strategy Analytics & 2009 & US\$ 6.4 billion \\
ABI Research & 2010 & US\$ 27 billion \\
Pyramid Research & 2010 & US\$ 13 billion - 28 billion \\
Frost \& Sullivan & 2011 & US\$ 8.1 billion \\
\hline
\end{tabular}

which are listed in Table 2[6]. AT\&T has announced that its MediaFLO based mobile TV service will be going live in May 2008. While Qualcom is in a position to leverage other technologies or use it for open access technologies such as WiMAX or use them for mobile services. It looks like that despite the EU having embraced a single standard for mobile TV, the US market will remain fragmented with multiple technologies.

According to mobile TV usage patterns identified in many worldwide trials TV content must adjust to mobile context of use $[3,4,5]$. Results of a Finnish study show that mobile TV users spent approximately 20 minutes a day watching mobile TV and more active users watched between 30 to 40 minutes per session [7]. Typical usage environments include transportation terminals (airport, train station, bus stop, etc.), in the moving vehicles, working places or at home. It is also found that smaller screens and the duration of usage may have significant influences on the types of mobile TV content as well as the way users' willingness to pay for mobile TV.

In Taiwan, a handheld TV experimental project was launched in October 2006. There were five teams participating in mobile TV trials in North and South Taiwan. The MediaFLO was tested in North Taiwan, while the DVB-H was chosen for South Taiwan. The experiment is expected 
Table 2. Overview of mobile TV solutions

\begin{tabular}{|c|c|c|c|c|}
\hline Technology & Major market & Standard Group & Industrial players & Comparisons \\
\hline DVB-H & $\begin{array}{l}\text { Europe, Asia, North } \\
\text { America, Australia }\end{array}$ & $\begin{array}{l}\text { DVB } \\
\text { OMA }\end{array}$ & $\begin{array}{l}\text { Nokia, BenQ - Siemens, } \\
\text { Motorola, Samsung, LG, } \\
\text { Alcatel, ... etc. }\end{array}$ & $\begin{array}{l}\text { IP based; } 90 \% \text { power saving design, either use } \\
\text { independent MUX, OR }\end{array}$ \\
\hline T-DMB & South Korea & $\mathrm{DAB}$ & LG, Samsung & $\begin{array}{l}\text { some proprietary; bit rate } 1.5 \mathrm{Mbps} \text {, non-IP based; } \\
\text { external antenna; less power saving; be con- } \\
\text { structed based on existing DAB network }\end{array}$ \\
\hline S-DMB & South Korea, Japan & $\mathrm{DAB}$ & LG, Samsung, Alcatel & $\begin{array}{l}\text { Some proprietary; non-IP based, big antenna; } \\
\text { power saving; satellite transmission with terres- } \\
\text { trial repeaters }\end{array}$ \\
\hline MediaFLO & North America & Qualcomm & $\begin{array}{l}\text { Qualcomm \& CDMA } \\
\text { manufacturers }\end{array}$ & Proprietary; non-IP based; bandwidth efficiency \\
\hline ISDB-T & Japan only & & & Proprietary \\
\hline MBMS & $3 \mathrm{G}$ service regions & 3GPP, 3GPP2 & Most 3G manufacturer & $\begin{array}{l}\text { Bit rate } 345 \mathrm{kbps} \sim 2 \mathrm{Mbps} \text {, IP based; based on } 3 \mathrm{G} \\
\text { network; standardization still in progress }\end{array}$ \\
\hline $\begin{array}{l}\text { IPTV over } \\
\text { WiMAX }\end{array}$ & $\begin{array}{l}\text { WiMAX service } \\
\text { regions }\end{array}$ & WiMAX Forum & Intel...etc. & standardization still in progress \\
\hline
\end{tabular}

to end no later than June 2008 and the formal licenses for mobile TV operators will be permitted after NCC's (National Communications Commission) official evaluations. Preliminary results of this experiment show that end-users will use mobile TV to fill in gaps in their daily schedules: waiting for the bus or subway, sitting in the train etc. In these situations mobile TV competes with other possibilities such as reading a book, listening to radio, playing a mobile game or just watching out the window. In these scenarios mobile TV might be an appealing choice, but only if it does not inflict significant costs. On the other hand, if the pricing is low enough, there might be quite large audiences awaiting the launch of mobile TV services. A logical choice might be to keep subscription prices as low as possible, thus maximize the popularity of mobile TV, and subsidize the lower subscription income with higher advertising revenue. In summary, these five teams together with three main telecommunication operators (CHT, TMT, FET) reach a consensus that a user-centered content design will contribute to future success of Taiwan's mobile TV market.

To survive in competitive mobile TV services markets, the operators need to determine who the target customers are, what motivates them and why they pay for the mobile TV content. This process is called market segmentation, by which companies are able to understand their loyal customers and concentrate their limited resources into them. Although there are many studies covering critical variables for market segmentation of mobile TV content, until now only few papers focus on public transportation systems with high speed, especially on the train [8]. Currently Taiwan Railway Administration's (TRA) is conducting a BOT project to implement mobile commerce services on the train. In addition, TRA's network is across north and south Taiwan, content diversity of mobile TV can be tested on the train countrywide. Theses advantages may attract the five teams to focus on certain killer applications for mobile TV.

The concept of segmentation in mobile TV marketing recognizes that consumers differ not only in the price they will pay, but also in a wide range of benefits they expect from the content. Good mobile TV content with compelling value-added services are provided by tight business and strategic partnership arrangements and by involving a large number of companies, with each influencing other parties in the value chain. Wang [9] identifies that powerful actors, such as carriers and the media industry's content providers must agree on business models that support the new ecosystem of mobile TV. Carlsson and Walden [7] conclude that mobile TV content is the key factor to determine the adoption and usage of mobile TV, especially when traveling with public transportation to and from work in order to relax or to keep up to date with the latest news.

This paper is aimed on proposing an integrated approach for market segmentation of mobile TV content on the train by integrating innovation adoption model and lifestyle theory. Figure 1 shows the conceptual framework of this integrated approach.

First, the mobile TV content is identified as the segmentation variable. And key factor facets for mobile TV content are redefined by using factor analysis. Then, the cluster analysis is used to classify consumer groups which are named by analysis of variance (ANOVA) and market segmentations are described with demographic, lifestyle and train patronage variables by using cross analysis and Chi-squared independence tests. Finally, empirical results are analyzed and the conclusion follows.

\section{Literature Review}

It is the first step for mobile TV companies to identify the 


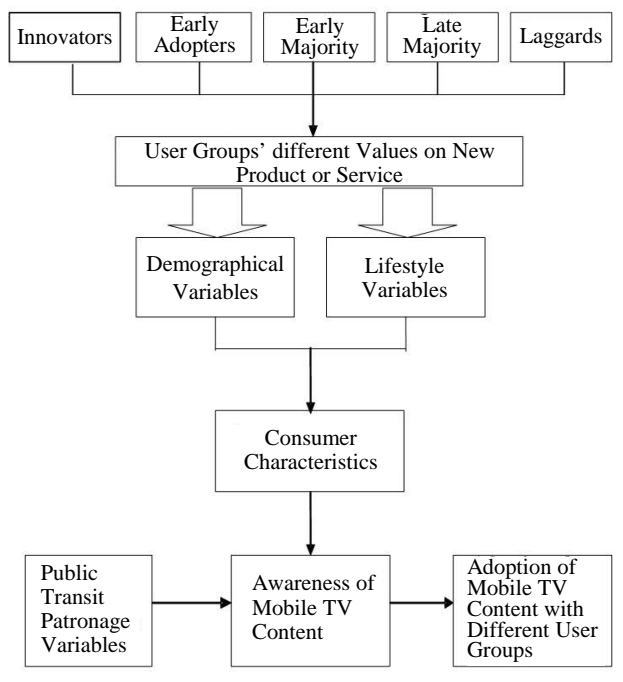

Figure 1. Conceptual framework of the integrated approach

primary variables of market segmentation to understand their customers' requirements, attitudes and habits. These primary variables called segmentation variables which can be derived from the technological, demographical and psychological, behavioral perspective, such as age, income, gender, occupation, attributes of product or service, personal interest, consumer awareness, perception. A review of prior studies suggests the theoretical foundations of the hypotheses formulations [10]. To achieve this goal, this paper examines two prevalent theories (lifestyle theory and innovation diffusion theory) for identifying individual acceptance of mobile TV content on the train.

Lifestyle is a key factor in determining the adoption rate for mobile TV content. Individuals will adopt given behavior patterns representative of their lifestyles, and as a consequence will purchase different types of mobile TV content. Many studies verified that behavioral variations in purchases even if there is no question of a mix of sociodemographical variables coming into play, lead to a need for research into lifestyle as a potentially influential factor. Market segmentation according to features of lifestyle divides the market into segments based on activities, interests, and opinions [11]. The lifestyle segmentation in this paper is defined by including variables like activities, referring to the way in which individuals spend their time and money; interests, which are those things in their immediate surroundings they consider more or less important; and opinions, the view they have of themselves and of the world around them. One of well-known lifestyle analysis methods is proposed by Wind and Green [12]. First, factor-groups influencing lifestyle patterns are reduced by using factor analysis. Then, the cluster analysis is used to classify consumer groups. The interrelationships among lifestyle patterns and other consumer behavioral variables are verified by cross analysis.
The innovation diffusion theory (IDT) is a well-known theory proposed by Rogers [13]. The adoption of mobile TV content on the train could be studied from the perspective of information technology innovations. IDT states that diffusion of an innovation depends on five general attributes including relative advantage, compatibility, complexity, observability, and trial ability. These characteristics are used to explain the user adoption and decision making process. They are also used to predict the implementation of new technological innovations and clarify how these variables interact with one another. The central concept of innovation diffusion is "the process in which an innovation is communicated through certain channels, over time, among the members of a social system.' However, research has suggested that only the relative advantage, compatibility, and complexity are consistently related to innovation adoption [14]. Relative advantage is similar to perceived usefulness, whereas complexity is similar to perceived ease of use. Compatibility is the degree to which the innovation is perceived to be consistent with the potential users' existing values, previous experiences, and needs [15]. High compatibility will lead to preferable adoption. Holak and Lehmann modified Rogers's model for measuring relative advantages [16]. They provided empirical evidence that relative advantage and compatibility "directly" affect consumers' purchase intention. The two factors have received favoritism in recent published articles in the area of product innovation. The two innovation characteristics are also peculiar in that they are defined in relation to existing products, while others (complexity, trial ability, and observability) indicate the innate characteristics of an innovation.

Originating in IDT research, different adopter groups perceive innovations and thus behave differently. Miller [17] finds that prior knowledge of potential adopters can focus the use of resources to prevent an innovation from failing. Innovation theory can be applied to identify the attitudes and behavior of early adopters, as a dynamic basis for a market segmentation model. Therefore, Holak's new product adoption model is used to examine the acceptance of mobile TV for public transportation users. Through the review of relevant literature, following variables of three dimensions for mobile TV content segmentation analysis shown in Table 3 are examined in this paper $[18,19,20]$ :

Table 3. Segmentation dimensions

\begin{tabular}{lll}
\hline \multicolumn{1}{c}{ Demographic } & \multicolumn{1}{c}{ Psychographic } & \multicolumn{1}{c}{ Behavioral } \\
\hline $\begin{array}{l}\text { Age, occupation, } \\
\text { gender, income, } \\
\text { religion, nationality, } \\
\text { education, marital } \\
\text { status, ethnicity }\end{array}$ & $\begin{array}{l}\text { Values, lifestyle, } \\
\text { ions, activities }\end{array}$ & $\begin{array}{l}\text { Product use pat- } \\
\text { terns, perceived } \\
\text { benefits (value- } \\
\text { added, ease of use, } \\
\text { usability, useful- } \\
\text { ness) }\end{array}$ \\
\hline
\end{tabular}


To identify links among what the mobile TV operators would know about their customers and the bundles of content they could offer, clustering algorithms are generally used as the primary methodology for market segmentation. Clustering analysis techniques have been discussed in details in the literature $[21,22,23]$. The most popular is $\mathrm{k}$ means algorithm which together with its modifications was broadly reviewed by different authors [24,25,26]. It is also found that algorithms using computational intelligence did not show better results than k-means, the combinations of several algorithms are very often recommended as the conclusion. Zakrwska and Murlewski [27] investigated the shortcomings and advantages of three algorithms of clustering analysis: k-means, two-step clustering and density based spatial clustering of applications with noise. Their numerical tests showed that k-means is very efficient for large multidimensional data sets, however depends strongly on the choice of input parameter $\mathrm{k}$. However, it is not recommended in the case of data sets with noise.

\section{Research Methodology}

\subsection{Research Design}

The framework of research design is shown in Figure 2. After conducting an interview survey (face-to-face) with questionnaires, the mobile TV content on the train is identified as the segmentation variable and key factor facets for mobile TV content are redefined by using factor analysis. Then, the cluster analysis (k-means) is used to classify consumer groups which are named by ANOVA. The market segmentations are described with content usage, demographic, lifestyle and train patronage variables by using cross analysis and Chi-squared independence tests. Finally, each segment market can be targeted with precise customer characteristics and those results are used as the starting point for providing the market strategies.

The first round survey with 90 questionnaires was conducted on the three train types from Taipei station to Taichung station from $22^{\text {nd }}$ to $28^{\text {th }}$ December 2007. After reviewing preliminary results, some question items were modified and new question items of lifestyle variables were supplemented. The second round survey with 500 questionnaires was conducted on the train from $18^{\text {th }}$ to $25^{\text {th }}$ January 2008. Two types of handheld devices NOKIA N77 and N92 were used to demonstrate mobile TV content. The valid sample consisted of 462 respondents.

\subsection{Research Model and Hypotheses}

The research model tested in this paper is shown in Figure 3. With this integrated approach the mobile TV content may be regarded as segmentation variables including willingness to use, time of usage, price of willingness to pay, type of payment, incentives to take train. The demographical variables (gender, occupation, age, income, education), lifestyle variables (knowledge-oriented, recreationoriented, high living quality-oriented, favorite information-oriented, price sensitive-oriented, fashion-oriented), train patronage variables (frequency, travel time, train type, trip purpose) are chosen as descriptive variables to depict customer characteristics.

The following hypotheses of the proposed constructs are based on prior studies in the relevant literature [10,14,15]:

$\mathrm{H}_{1 \mathrm{a}}$ : No significant difference exists between each segment and gender.

$\mathrm{H}_{1 \mathrm{~b}}$ : No significant difference exists between each segment and occupation.

$\mathrm{H}_{1 \mathrm{c}}$ : No significant difference exists between each segment and age.

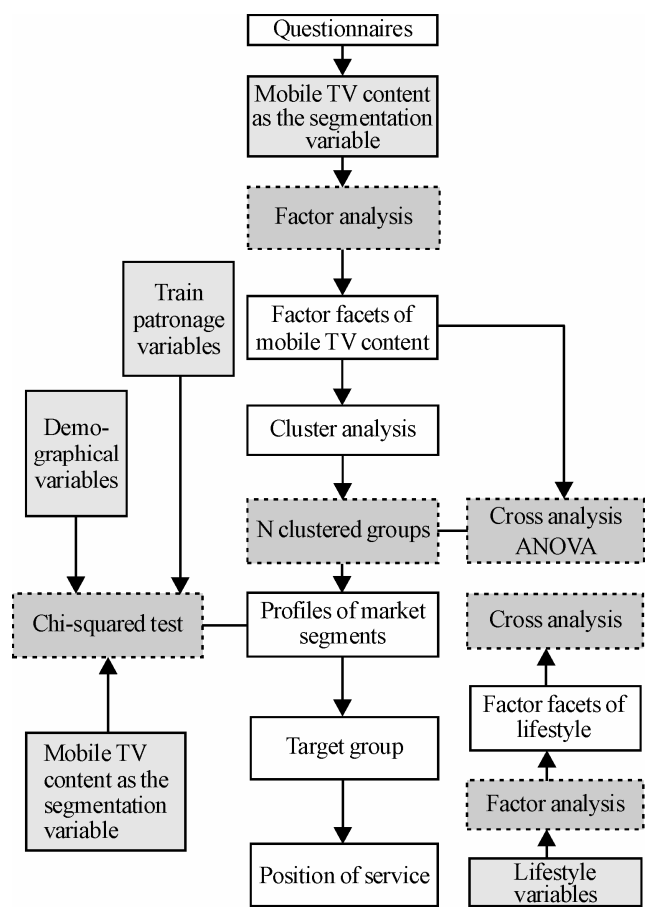

Figure 2. Framework of research design

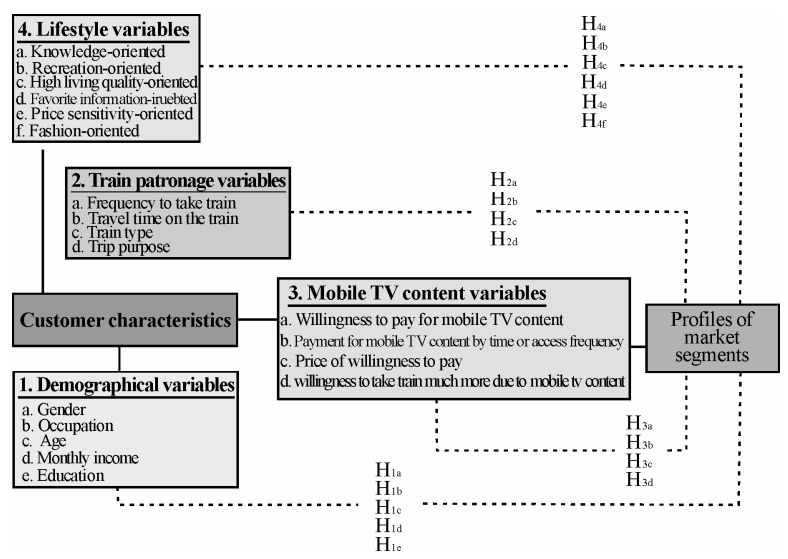

Figure 3. Research model and hypotheses 
$\mathrm{H}_{1 \mathrm{~d}}$ : No significant difference exists between each segment and income.

$\mathrm{H}_{1 \mathrm{e}}$ : No significant difference exists between each segment and education.

$\mathrm{H}_{2 \mathrm{a}}$ : No significant difference exists between each segment and frequency to take train.

$\mathrm{H}_{2 \mathrm{~b}}$ : No significant difference exists between each segment and travel time on the train.

$\mathrm{H}_{2 \mathrm{c}}$ : No significant difference exists between each segment and train type.

$\mathrm{H}_{2 \mathrm{~d}}$ : No significant difference exists between each segment and trip purpose.

$\mathrm{H}_{3 \mathrm{a}}$ : No significant difference exists between each segment and willingness to pay for mobile TV content.

$\mathrm{H}_{3 \mathrm{~b}}$ : No significant difference exists between each segment and payment for mobile TV content by time or access frequency.

$\mathrm{H}_{3 \mathrm{c}}$ : No significant difference exists between each segment and price of willingness to pay.

$\mathrm{H}_{3 \mathrm{~d}}$ : No significant difference exists between each segment and willingness to take train much more due to mobile TV content.

$\mathrm{H}_{4 \mathrm{a}}$ : No significant difference exists between each segment and knowledge-oriented lifestyle.

$\mathrm{H}_{4 \mathrm{~b}}$ : No significant difference exists between each segment and recreation-oriented lifestyle.

$\mathrm{H}_{4 \mathrm{c}}$ : No significant difference exists between each segment and high living quality-oriented lifestyle.

$\mathrm{H}_{4 \mathrm{~d}}$ : No significant difference exists between each segment and favorite information-oriented style.

$\mathrm{H}_{4 \mathrm{e}}$ : No significant difference exists between each segment and price sensitive-oriented lifestyle.

$\mathrm{H}_{4 \mathrm{f}}$ : No significant difference exists between each segment and fashion-oriented lifestyle.

\section{Results Analysis}

The descriptive statistics of demographical variables and train patronage variables are summarized as follows:
1) A total of $48 \%$ of the respondents were male. The age of most respondents was from 19 to 33 years old with a total of $64 \% .70 \%$ of them were college educated, $29 \%$ were students and $55 \%$ working in service industry and trade. $31 \%$ of respondents earn under US $\$ 300$ per month and $21 \%$ earning US $\$ 800-1000$ per month.

2) $23 \%$ of total respondents take train at least one time daily and $31 \%$ taking at least one time per week. $36 \%$ of them were commuters for work and school, and $25 \%$ were leisure or tourism travelers. The percentage of travel time from 31-60 minutes was 33\% due to short-trip distance. A total of $34 \%$ and $36 \%$ of the respondents most often take the EMU commuter train type and "Zhi-Chiang" express train type, respectively.

Factor analysis utilized the principal axis factoring method in order to identify underlying constructs. The KMO measure of sampling adequacy and Barlett's tests of sphericity provided support for the validity of the factor analysis of the data set. The varimax rotation facilitated interpretability.

The major mobile TV content consists of seven factor facets which together explained $72.1 \%$ of the total variation shown in Table 4.

Factor facets are thus named: films, news, documentaries, sports, leisure \& tourism, entertainment and drama. Measure validation was also examined for internal consistency by computing Cronbach's $\alpha$ coefficient. The average Cronbach's $\alpha$ value was found to be greater than 0.8 , in accordance with Nunnally's standard [28]. The same procedure of factor analysis for lifestyle variables was also conducted to obtain following factor facets with a satisfied average Cronbach's $\alpha$ value 0.7: knowledge-oriented type, recreation-oriented type, high living quality-oriented type, favorite information-oriented type, price sensitiveoriented type and fashion-oriented type.

Table 4. Results of mobile TV content by factor analysis

\begin{tabular}{|c|c|c|c|c|c|c|c|c|c|}
\hline \multirow{2}{*}{ Component } & \multicolumn{3}{|c|}{ Initial Eigen-values } & \multicolumn{3}{|c|}{ Extraction Sums of Squared Loading } & \multicolumn{3}{|c|}{ Rotation Sums of Squared Loading } \\
\hline & Total & $\%$ of Variance & Cumulative \% & Total & $\%$ of Variance & Cumulative $\%$ & Total & $\%$ of Variance & Cumulative $\%$ \\
\hline (Films) & 12.71 & 27.80 & 27.80 & 12.71 & 27.80 & 9.32 & 23.21 & 23.21 & 23.21 \\
\hline 2(News) & 7.24 & 13.41 & 41.21 & 7.24 & 13.41 & 7.57 & 12.16 & 12.16 & 35.37 \\
\hline 3(Documeutaries) & 4.18 & 10.06 & 51.27 & 4.18 & 10.06 & 3.98 & 9.89 & 9.89 & 45.26 \\
\hline 4(Sports) & 2.26 & 7.02 & 58.29 & 2.26 & 7.02 & 3.70 & 9.34 & 9.34 & 54.60 \\
\hline 5(Leisure \& Tourism) & 1.60 & 6.22 & 64.51 & 1.60 & 6.22 & 2.53 & 8.22 & 8.22 & 62.82 \\
\hline 6 (Entertainment) & 1.25 & 4.55 & 69.05 & 1.25 & 4.55 & 1.95 & 6.19 & 6.19 & 69.02 \\
\hline 7(Drama) & 1.04 & 3.01 & 72.07 & 1.04 & 3.01 & 1.22 & 3.06 & 3.06 & 72.07 \\
\hline 8 (Weather forecasts) & 0.99 & 2.79 & 74.85 & & & & & & \\
\hline 9(Stock reporting) & 0.97 & 2.59 & 77.44 & & & & & & \\
\hline 10(Religion tallking) & 0.936 & 2.516 & 79.96 & & & & & & \\
\hline
\end{tabular}


Then based on cluster analysis of six factor scores for lifestyle variables, the whole sample was classified into three groups: Group 1 (Group of being fashion and optimistic), Group 2 (Group of being leisured and living information-oriented) and Group 3 (Group of being conservative and traditional). ANOVA was conducted and the results reveal that there are significant differences among three groups on each factor scores.

The hypothesized relationships in Figure 3 are tested using ANOVA, cross analysis and Chi-squared test to examine if there is enough evidence to infer that two research variables are related. Results of hypotheses tests with P-value, Chi-squared values or F-value are summarized in Table 5 .

As shown in Table 5, approximately $60 \%$ of all hypotheses are proven to have significant differences at the $95 \%$ level.

To identify characteristics and the structure of the market segments, a summarized analysis was conducted to compare results of mobile TV content, demographical, train patronage and lifestyle variables including gender, occupation, age, income, education, frequency to take train, travel time on the train, train type, trip purpose, willingness to pay for mobile TV content, payment by time or frequency, price of willingness to pay, type of lifestyle, favorite content and willingness to take train due to mobile TV content. The summarized profiles are shown in Table 6.

As to the key information in the target group, the gender is male, monthly income is under US $\$ 300$, the age is from 19 to 33 years old. They are high school and college students and spend 31-90 minutes on the train per trip They will pay either US $\$ 0.25 / \mathrm{h}$ or US $\$ 0.5$ for one usage during the travel time between 61 and 121 minutes and over 121 minutes. Their lifestyle types include entertainment-oriented, fashion-oriented, price sensitivityoriented. Their favorite content includes films, news, entertainment, documentaries and leisure \& tourism. They are willing to take train much more if TRA offers more interesting mobile TV content.

Table 5. Results of hypotheses tests

\begin{tabular}{cclcc}
\hline Hypothesis & P-value & $\begin{array}{c}\text { Chi-squared }\left(x^{2}\right) \\
\text { / F-value }\end{array}$ & Accept & Reject \\
\hline $\mathrm{H}_{1 \mathrm{a}}$ & 0.005 & $10.502\left(x^{2}\right)$ & $\sqrt{ }$ & \\
$\mathrm{H}_{1 \mathrm{~b}}$ & 0.010 & $29.287\left(x^{2}\right)$ & & $\times$ \\
$\mathrm{H}_{1 \mathrm{c}}$ & 0.021 & $28.165\left(x^{2}\right)$ & & $\times$ \\
$\mathrm{H}_{1 \mathrm{~d}}$ & 0.012 & $22.760\left(x^{2}\right)$ & & $\times$ \\
$\mathrm{H}_{1 \mathrm{e}}$ & 0.467 & $7.666\left(x^{2}\right)$ & $\sqrt{ }$ & \\
$\mathrm{H}_{2 \mathrm{a}}$ & 0.596 & $4.602\left(x^{2}\right)$ & $\sqrt{ }$ & \\
$\mathrm{H}_{2 \mathrm{~b}}$ & 0.002 & $24.890\left(x^{2}\right)$ & & $\times$ \\
$\mathrm{H}_{2 \mathrm{c}}$ & 0.668 & $4.068\left(x^{2}\right)$ & $\sqrt{ }$ & \\
$\mathrm{H}_{2 \mathrm{~d}}$ & 0.043 & $11.946\left(x^{2}\right)$ & $\sqrt{ }$ & \\
$\mathrm{H}_{3 \mathrm{a}}$ & 0.022 & $11.463\left(x^{2}\right)$ & $\sqrt{ }$ & \\
$\mathrm{H}_{3 \mathrm{~b}}$ & 0.096 & $4.692\left(x^{2}\right)$ & $\sqrt{ }$ & \\
$\mathrm{H}_{3 \mathrm{c}}$ & 0.032 & $19.678\left(x^{2}\right)$ & & $\times$ \\
$\mathrm{H}_{3 \mathrm{~d}}$ & 0.000 & $22.980\left(x^{2}\right)$ & & $\times$ \\
$\mathrm{H}_{4 \mathrm{a}}$ & 0.597 & $0.516(\mathrm{~F})$ & $\sqrt{ }$ & \\
$\mathrm{H}_{4 \mathrm{~b}}$ & 0.000 & $21.63(\mathrm{~F})$ & & $\times$ \\
$\mathrm{H}_{4 \mathrm{c}}$ & 0.020 & $11.37(\mathrm{~F})$ & $\sqrt{ }$ & \\
$\mathrm{H}_{4 \mathrm{~d}}$ & 0.179 & $1.72(\mathrm{~F})$ & $\sqrt{ }$ & \\
$\mathrm{H}_{4 \mathrm{e}}$ & 0.048 & $2.05(\mathrm{~F})$ & $\sqrt{ }$ & \\
$\mathrm{H}_{4 \mathrm{f}}$ & 0.000 & $5.76(\mathrm{~F})$ & & $\times$ \\
\hline
\end{tabular}

Table 6. Profiles of market segments

\begin{tabular}{|c|c|c|c|}
\hline & Group 1 (fashion and optimistic) & $\begin{array}{l}\text { Group2 (leisured and living } \\
\text { information-oriented) }\end{array}$ & $\begin{array}{l}\text { Group3 (conservative and } \\
\text { traditional) }\end{array}$ \\
\hline Sample size & 193 & 94 & 175 \\
\hline Grender & Male $>$ Female & Female $>$ Male & Male $=$ Female \\
\hline Occupation & College students & Service industry and trade & Uniformly distributed \\
\hline Age & 19-33 years old & 14-42 years old & Uniformly distributed \\
\hline Average income per month & Under US \$ 300 & US \$ 800-100 & US \$ 800-1500 \\
\hline Education & College and high school & College & High school \\
\hline Frequency to take train & No distinct segments & No distinct segments & No distinct segments \\
\hline Travel time on the train & More than 90 minutes & $31-90$ minutes & 31-60 minutes \\
\hline Train type & Zhi-Chiang and EMU & Zhi-Chiang and EMU & Zhi-Chiang and EMU \\
\hline Trip purpose & $\begin{array}{l}\text { Commuter, Homebound traveler, } \\
\text { leisure traveler }\end{array}$ & Commuter, leisure traveler & Unifornly distributed \\
\hline Willingness to use mobile TV & $\begin{array}{l}\text { Yes for travel time between } 61 \text { and } \\
121 \text { minutes and over } 121 \text { minutes }\end{array}$ & $\begin{array}{l}\text { Yes for travel time between } \\
61 \text { and } 121 \text { miuutes and over } \\
121 \text { minutes }\end{array}$ & $\begin{array}{l}\text { Yes for travel time over } 121 \\
\text { minutes }\end{array}$ \\
\hline Payment by time or frequency & both & Prefer by frequency & Prefer by frequency \\
\hline Price of willingness to pay & US $\$ 0.25 / \mathrm{h}$ and US $\$ 0.5$ for one usage & US $\$ 0.5$ for one usage & US $\$ 0.3$ for one usage \\
\hline Type of lifestyle & $\begin{array}{l}\text { Entertainment-oriented, high living } \\
\text { quality-oriented and fashion-oriented }\end{array}$ & High living quality-oriented & Price sensitive-oriented \\
\hline Favorite content & $\begin{array}{l}\text { News, films, entertainment, documen- } \\
\text { taries }\end{array}$ & $\begin{array}{l}\text { News, films, leisure \& tour- } \\
\text { ism, entertainment }\end{array}$ & No preference \\
\hline $\begin{array}{l}\text { Duration of watching mobile } \\
\text { TV content }\end{array}$ & More than 30 minutes & 20-30 minutes & No preference \\
\hline $\begin{array}{l}\text { Willingness to take train due } \\
\text { to mobile TV content }\end{array}$ & $\begin{array}{l}\text { Yes for the travel time over } \\
90 \text { minutes }\end{array}$ & $\begin{array}{l}\text { Yes for the travel time over } \\
90 \text { minutes }\end{array}$ & Yes for cheaper fares only \\
\hline
\end{tabular}




\section{Conclusions}

This paper identifies the new primary factors for mobile TV content on the train which may not found in the previous studies. Additionally, this paper proposes a concise framework of research methodology for market segmentation and user preferences for mobile TV content on the train.

However, the proposed approach is applicable to the case of "on the train". The case of "railway networks" which fully represents mobile TV content anywhere and anytime in stations and trains needs to be researched further. It is also recognized that many other facets of individual differences (e.g., psychological type, cognitive processing skills etc.) may be candidate variables for lifestyle consideration.

\section{REFERENCES}

[1] N. Holland, et al., "Rescuing 3G with Mobile TV: Buinsess Models and Monetizing 3G," Pyramid Research, March 2006.

[2] Wireless World Forum, "Mobile Youth 06 Video," mobileYouth06-part one, July 2006.

[3] J. Trefzger, "Mobile TV-launch in germany-challenges and implications," working paper No. 209, Institute for Broadcasting Economics, Cologne University, Germany, 2005.

[4] S. Orgad, "How will mobile tv transform viewer's experience and change advertising," Final report, Dept. of Media and Communications, London School of Economics and Political Science, November 2006.

[5] QuickPlayMedia, "Mobile TV and video survey 2008," Toronto, Canada, 2008.

[6] M. P. Shih, "Analysis of mobile TV and its key success factors: from the perspective of mobile operator," Proceedings of International Symposium on HDTV and Mobile TV, Taipei, Taiwan, 2007.

[7] C. Carlsson and P. Walden, " Mobile TV-to live or die by content," Proceedings of the 40th Hawaii International Conference on System Sciences, IEEE, Hawaii, USA, 2007.

[8] C. M. Tan and C. C. Wong, "Mobile broadband race: Friend or foe," Proceedings of the International Conference on Mobile Business, IEEE, ICMB'06, 2006.

[9] G. Wang, "Mobile TV value chain and operator strategies," Master's Thesis, Dept. of Communication Systems, School of Information and Communication Technology, KTH, Finland, February 2007.

[10] T. M. Lee and J. K. Jun, "Contextual perceived usefulness? toward an understanding of mobile commerce acceptance", Proceedings of the International Conference on Mobile Business, IEEE, ICMB'05, 2005.

[11] J. T. Plummer, "The concept and application of lifestyle segmentation," Journal of Marketing, pp. 33-74, January 1974.
[12] Y. Wind and P. E. Green, "Some conceptual measurement and analytical problem in life style research," Life style and Psychographics, Chicago, AMA, 1974.

[13] E. Rogers, Diffusion of Innovation, Free Press, New York, 1962.

[14] J. H. Wu and S. C. Wang, "What drives mobile commerce? An empirical evaluation of the revised technology acceptance model," Information \& Management 42, pp.719729, 2005.

[15] Y. Shin, H. Jeon, and M. Choi, "Analysis of the consumer preferences toward m-commerce applications based on an empirical study," Proceedings of International Conference on Hybrid Information Technology, IEEE, ICHIT'06, 2006.

[16] S. L. Holak and D. R. Lehmann, "Purchase intentions and the dimensions of innovation: An exploratory model," Journal of Product Innovation Management, 7 (1), pp. 5973, 1990.

[17] R. N. Miller, "Target marketing," Multinational Marketing, Vol. 13, No. 10, 1993.

[18] A. L. Gilbert and J. D. Kendall, "A marketing model for mobile wireless services," Proceedings of the 36th Hawaii International Conference on System Science (HICSS'03), 2003.

[19] H. H. Lin and Y. S. Wang, "Predicting consumer intention to use mobile commerce in taiwan," Proceedings of the International Conference on Mobile Business (ICMB'05), 2005.

[20] H. Feng, T. Hoegler, and W. Stucky, "Exploring the critical success factors for mobile commerce," Proceedings of the International Conference on Mobile Business (ICMB'06), 2006.

[21] C. C. Aggarwal, C. Procopiuc, J. S. Wolf, P. S. Yu, and J. S. Park, "Fast algorithms for projected clustering," Proceedings of SIGMOD Conference, Philadelphia, 1999.

[22] A. K. Jain, M. N. Murty, and P. J. Flynn, "Data clustering: A review," ACM Computing Surveys, Vol. 31, No. 3, September 1999.

[23] M. Zait and H. Messatfa, "A comparative study of clustering methods," FGCS Journal, Special Issue on Data Mining, 1997.

[24] P. V. Balakrishnan, M. C. Cooper, V. S. Jacob, and P. A. Lewis, "Comparative performance of the fscl neural net and k-means algorithm for market segmentation," European Journal of Operational Research, No. 93, 1996.

[25] H. Hruschka and M. Natter, "Comparing performance of feedforward neural nets and k-means for cluster-based market segmentation," European Journal of Operational Research, No. 114, 1999.

[26] C. Y. Tsai and C. C. Chiu, "A purchased-based market segmentation methodology", Expert Systems with Applications, No. 27, 2004.

[27] D. Zakrzewska and J. Murlewski, "Clustering algorithms for bank customer segmentation", Proceedings of the 5th International Conference on Intelligent Systems Design and Applications (ISDA'05), 2005.

[28] J. C. Nunnally, Psychometric Theory, McGraw-Hill, New York, 1967. 